\title{
9. LOW-TEMPERATURE ALTERATION AND SUBSEQUENT REHEATING OF SHALLOW OCEANIC CRUST AT HOLE 765D, ARGO ABYSSAL PLAIN ${ }^{1}$
}

\author{
Kathryn M. Gillis, ${ }^{2}$ John N. Ludden, ${ }^{3}$ Terry Plank, ${ }^{4}$ and Lawrence D. Hoy ${ }^{3}$
}

\begin{abstract}
Volcanic basement recovered at Hole 765D is characterized by nonpervasive, oxidative alteration, typical of seafloor weathering. Chilled margins and the mesostasis of the lavas are variably altered to assemblages of celadonite, Fe-oxyhydroxides, zeolites, and calcite with trace saponite. Plagioclase is partially altered to Ca-Na zeolites and/or albite. Well-developed alteration halos parallel fracture surfaces and extend several centimeters into the surrounding rock. These clay-rich halos are enriched in $\mathrm{K}_{2} \mathrm{O}_{\text {and }} \mathrm{Fe}_{2} \mathrm{O}_{3}$ relative to the adjacent clay-poor rock. The halos and adjacent rock are characterized by $\delta^{18} \mathrm{O}$ values $2 \%-3 \%$ higher than those of fresh MORB. The "freshness" of the samples and the scarcity of saponite suggest that the duration of seawater circulation was short-lived. Albitization of plagioclase indicates that the volcanic rocks were altered initially at low temperatures and were subsequently reheated off-axis in a closed environment. Reheating did not result in significant modification of the bulk composition of the crust.
\end{abstract}

\section{INTRODUCTION}

Despite differences in geologic setting and age, the mineralogical and geochemical characteristics of Deep Sea Drilling Project/Ocean Drilling Program (DSDP/ODP) shallow basement cores are remarkably similar (e.g., Honnorez, 1981). All show evidence for seawater-rock interaction at low temperatures and moderate to high water/rock ratios. Consistent sequences of secondary mineral deposition in voids document progressive stages of alteration, from early, rock-dominated to later, seawater solutions (Staudigel et al., 1981; Alt and Honnorez, 1984). Although the duration of seawater-rock interaction is dependent upon factors such as the longevity of exposure to cold seawater and the rate that cracks are filled, isotopic age dating indicates that secondary mineral deposition in the shallow crust generally ceases within 10 to 20 m.y. of crustal formation (Staudigel et al., 1981; Staudigel and Hart, 1985).

The alteration patterns of the basement core recovered at Site 765 in the Argo Abyssal Plain are similar to those of other shallow basement cores. The absence of pervasive alteration, the preservation of fresh glass, and the presence of well-developed alteration halos permit detailed study of interaction between seawater and fractured oceanic crust. The mineralogical and geochemical characteristics of the alteration halos are documented here. A two-stage model for the evolution of the alteration patterns is proposed. The first stage involves low-temperature oxidative alteration in an environment open to seawater penetration and circulation. The second stage involves off-axis, conductive reheating of the crust, after the crust has been closed to seawater penetration by the deposition of clay-rich sediments and circulation inhibited by the precipitation of secondary minerals in voids.

\footnotetext{
${ }_{1}^{1}$ Gradstein, F. M., Ludden, J. N., et al., 1992. Proc. ODP, Sci. Results, 123 College Station, TX (Ocean Drilling Program).

${ }^{2}$ Department of Geology and Geophysics, Woods Hole Oceanographic Institution, Woods Hole, MA 02543, U.S.A.

${ }^{3}$ Mineral Exploration Research Institute and Dept. de Géologie, Université de Montréal, C.P. 6128, Succ. A, Montréal, Quebec H3C 3J7, Canada.

${ }^{4}$ Lamont-Doherty Geological Observatory, Columbia University, Palisades, NY 10964 , U.S.A.
}

\section{GEOLOGIC SETTING}

Site 765 is located within 25 to $75 \mathrm{~km}$ of the northwestern Australian margin on the southern Argo Abyssal Plain, eastern Indian Ocean $\left(15^{\circ} 58.541^{\prime} \mathrm{S}, 117^{\circ} 34.459^{\prime} \mathrm{E}\right)$. Biostratigraphic ages of the lowermost sediments indicate deposition between 138 and $142 \mathrm{Ma}$ (Berriasian; McMinn, this volume), and the location of this site on marine magnetic anomaly M25 indicates a basement age of $156 \pm 3 \mathrm{Ma}$ (Fullerton et al., 1989). ${ }^{40} \mathrm{Ar} /{ }^{39} \mathrm{Ar}$ age data for volcanic glasses and $\mathrm{K} / \mathrm{Ar}$ ages for secondary celadonite give an age of $155 \pm 3 \mathrm{Ma}$ (Ludden, this volume).

The volcanic basement in this area is overlain by a 1-km-thick sequence of Lower Cretaceous to Quaternary sediments. The Cretaceous sediments include noncalcareous claystones, radiolarites, and altered ash layers. These clay-rich sediments are overlain by a Tertiary sequence of calcareous turbidites and interbedded claystones. The lowermost sediments contain significant quantities of smectite and bentonite (Compton et al., this volume), indicating an active volcanic environment during the first several million years of sedimentation. The age difference between the basal sediments and volcanic basement suggests a low rate of sedimentation and a discontinuous sedimentary cover in the Jurassic. In contrast, the alteration characteristics of the Hole 765D core suggest that the basement section was sealed from seawater penetration early in its history.

At Hole 765D, $247 \mathrm{~m}$ of volcanic basement was drilled, with an average recovery of $31 \%$. Twenty-two lithologic units were identified on the basis of lithology and bulk-rock geochemistry. Massive flows comprise $28 \%$, pillow lavas $54 \%$, brecciated pillow basalts $8 \%$, autoclastic breccias $6 \%$, and diabases $4 \%$ of the recovered cores (Shipboard Scientific Party, 1990). The volcanic rocks are aphyric to sparsely plagioclase and/or olivine-phyric and are typical mid-ocean ridge tholeiites from the Indian Ocean.

\section{RESULTS}

\section{Secondary Mineralogy}

\section{Techniques}

Secondary mineral assemblages were determined optically, by $\mathrm{X}$-ray diffraction (XRD) and by microprobe analyses. XRD analyses were performed on air-dried smear mounts using a Phillips diffractometer. All samples with clay minerals were scanned from $2^{\circ}$ to $50^{\circ} 2 \theta$, glycolated overnight, and rescanned from $2^{\circ}$ to $20^{\circ} 2 \theta$. 
Major element analyses of minerals were determined at the Massachusetts Institute of Technology with a JEOL 733 Superprobe equipped with Tracor Northern software. Standard on-line correction schemes include Bence-Albee and Ziebold-Ogilvie. One notable feature of this machine is a high-resolution backscatter imaging system that can depict zoning in mineral phases on a very fine scale (e.g., $<5 \mathrm{~mol} \%$ anorthite over $1-2 \mu \mathrm{m}$ ). Structural formulas of the clay minerals were calculated following the method of Ross and Hendricks (1945); iron was considered $\mathrm{Fe}^{3+}$ for celadonite and celadonite-nontronite mixtures and $\mathrm{Fe}^{2+}$ for saponite.

\section{Clay Minerals}

Celadonite and mixtures of celadonite and nontronite are the most common clay minerals in the basement section of Hole 765D. Celadonite was identified by its nonexpandable basal 001 reflection at $10.5-11.0 \AA$ and its distinctive bluish green color. The presence of a small expandable peak at $16 \AA$ and high $\mathrm{Al}$ contents show that celadonite is mixed with smectite in some samples (Table 1). Calculated structural formulas indicate that most of these mixed clays are dioctahedral, suggesting that celadonite is mixed with nontronite. Both celadonite and celadonitenontronite mixtures are $\mathrm{Fe}$ rich, and celadonite has higher $\mathrm{K}_{2} \mathrm{O}$ contents than celadonite-nontronite (Fig. 1). Mixtures of celadonite and $\mathrm{Fe}$-oxyhydroxides are indicated by high $\mathrm{Fe}$ and $\mathrm{K}$ contents and the orange-brown color of some groundmass clay minerals (Table 1 and Fig. 1). Protoceladonite, a trioctahedral clay mineral with an XRD pattern of saponite and the chemical characteristics of celadonite (Donnelly et al., 1979; Adamson and Richards, 1990), was not identified in the Hole 765D samples.
Smectite, identified by its broad 001 basal reflection at $16 \AA$, which shifts to $18 \AA$ upon glycolation, occurs primarily as an alteration product of volcanic glass. Yellowish green smectite occurs locally as a groundmass phase, where it is associated with $\mathrm{Fe}$-oxyhydroxides or celadonite. Microprobe analyses show that the groundmass variety of smectite is saponite and that it is more $\mathrm{Mg}$ rich than celadonite (Fig. 1).

\section{Zeolites}

Several varieties of zeolites occur as replacement products of volcanic glass or plagioclase and as void-filling phases. Phillipsite and analcime, identified by XRD, are alteration products of volcanic glass, whereas radiating tabular clinoptilolite fills vesicles in a few samples. Analcime, chabazite, and mesolite, which locally replace plagioclase, were distinguished on the basis of their $\mathrm{Si} / \mathrm{Al}$ ratio, alkali/alkaline earth content, and optical characteristics. Other varieties of $\mathrm{Na}-\mathrm{Ca}$ zeolites were analyzed, but were not positively identified. Additional XRD analyses are in progress.

Analcime and mesolite are close to their end-member compositions, whereas chabazite is considerably more Na rich than its ideal formula (Table 2). Clinoptilolite is distinguished from heulandite by its $(\mathrm{Na}+\mathrm{K}) / \mathrm{Ca}$ ratio (Boles, 1972) and higher $\mathrm{Si} / \mathrm{Al}$ ratio (Mumpton, 1960).

\section{Carbonates}

Calcite occurs throughout Hole $765 \mathrm{D}$, filling fractures and, locally, vesicles. It is most abundant in lithologic units where tectonic breccias dominate. Several stages of growth are commonly indicated by successive layers of euhedral crystals in

Table 1. Representative clay mineral analyses, Hole 765D.

\begin{tabular}{|c|c|c|c|c|c|c|c|c|c|c|}
\hline \multirow{2}{*}{$\begin{array}{l}\text { Core, section, } \\
\text { interval }(\mathrm{cm}) \\
\text { Mineral }\end{array}$} & \multicolumn{2}{|c|}{$1 \mathrm{R}-2,30-34$} & \multirow{2}{*}{$\begin{array}{c}\text { 2R-3, } \\
122-127 \\
\\
\text { Celadonite- } \\
\text { nontronite } \\
\text { mixture } \\
\text { (groundmass) }\end{array}$} & \multicolumn{3}{|c|}{$5 R-3,110-117$} & \multicolumn{2}{|c|}{$7 \mathrm{R}-3,0-7$} & \multicolumn{2}{|c|}{$19 \mathrm{R}-1,115-121$} \\
\hline & $\begin{array}{c}\text { Celadonite } \\
\text { (vein) }\end{array}$ & $\begin{array}{l}\text { Saponite } \\
\text { (ground- } \\
\text { mass) }\end{array}$ & & $\begin{array}{l}\text { Celadonite } \\
\text { (ground- } \\
\text { mass) }\end{array}$ & $\begin{array}{l}\text { Celadonite } \\
\text { (vein) }\end{array}$ & $\begin{array}{l}\text { Saponite } \\
\text { (ground- } \\
\text { mass) }\end{array}$ & $\begin{array}{c}\text { Celadonite-Fe } \\
\text { oxyhydroxides } \\
\text { mixture } \\
\text { (groundmass, } \\
\text { green zone) }\end{array}$ & $\begin{array}{l}\text { Celadonite- } \\
\text { nontronite } \\
\text { mixture } \\
\text { (groundmass, } \\
\text { green zone) }\end{array}$ & $\begin{array}{l}\text { Celadonite } \\
\text { (vein) }\end{array}$ & $\begin{array}{c}\text { Celadonite } \\
\text { (vein) }\end{array}$ \\
\hline \multicolumn{11}{|c|}{ Major element composition (wt\%) } \\
\hline $\mathrm{SiO}_{2}$ & 54.28 & 47.45 & 49.80 & 54.06 & 53.47 & 44.53 & 37.71 & 51.95 & 53.70 & 47.88 \\
\hline $\mathrm{Al}_{2} \mathrm{O}_{3}$ & 0.92 & 5.62 & 10.00 & 1.43 & 0.70 & 6.03 & 3.93 & 6.04 & 2.85 & 4.36 \\
\hline $\mathrm{Fe}_{2} \mathrm{O}_{3} \mathrm{~T}$ & 20.17 & 10.74 & 15.60 & 20.92 & 24.49 & 13.25 & 30.31 & 16.93 & 18.71 & 19.75 \\
\hline $\mathrm{MnO}$ & 0.10 & 0.08 & - & 0.02 & 0.03 & 0.05 & - & 0.12 & 0.04 & 0.07 \\
\hline $\mathrm{MgO}$ & 7.17 & 15.91 & 4.60 & 5.82 & 5.25 & 15.29 & 3.78 & 5.30 & 6.82 & 3.87 \\
\hline $\mathrm{CaO}$ & 0.31 & 1.45 & 0.78 & 0.27 & 0.27 & 1.07 & 0.53 & 0.95 & 0.30 & 0.56 \\
\hline $\mathrm{Na}_{2} \mathrm{O}$ & 0.03 & 0.048 & 0.13 & 0.05 & - & - & 0.09 & 0.08 & - & - \\
\hline $\mathrm{K}_{2} \mathrm{O}$ & 8.45 & 0.09 & 6.79 & 7.20 & 6.50 & 0.29 & 4.67 & 5.96 & 8.01 & 5.59 \\
\hline Total & 91.43 & 81.39 & 87.70 & 89.77 & 90.71 & 81.51 & 81.02 & 87.33 & 90.43 & 86.02 \\
\hline \multicolumn{11}{|c|}{ Cation proportions on the basis of $22(\mathrm{O}, \mathrm{OH})$} \\
\hline $\mathrm{Si}$ & 7.86 & 7.5 & 7.36 & 7.91 & 7.88 & 7.26 & 6.4 & 7.69 & 7.80 & 7.62 \\
\hline $\mathrm{Al}^{\mathrm{VI}}$ & 0.14 & 0.5 & 0.64 & 0.09 & 0.12 & 0.74 & 0.79 & 0.31 & 0.20 & 0.38 \\
\hline Total & 8.00 & 8.00 & 8.00 & 8.00 & 8.00 & 8.00 & 7.19 & 8.00 & 8.00 & 8.00 \\
\hline $\mathrm{Al}^{\mathrm{IV}}$ & 0.02 & 0.55 & 1.10 & 0.16 & - & 0.42 & - & 0.74 & 0.29 & 0.44 \\
\hline $\mathrm{Fe}$ & 2.44 & 1.42 & 1.92 & 2.56 & 3.02 & 1.80 & 4.3 & 2.09 & 2.27 & 2.63 \\
\hline $\mathrm{Mg}$ & 1.55 & 3.76 & 1.01 & 1.27 & 0.87 & 3.72 & 0.96 & 1.17 & 1.48 & 0.92 \\
\hline Total & 4.01 & 5.73 & 4.03 & 3.99 & 3.89 & 5.94 & 5.26 & 4.00 & 4.04 & 3.99 \\
\hline $\mathrm{Ca}$ & 0.05 & 0.25 & 0.12 & 0.04 & 0.05 & 0.19 & 0.10 & 0.15 & 0.05 & 0.10 \\
\hline K & 1.56 & - & 1.28 & 1.34 & 1.22 & 0.06 & 1.01 & 1.12 & 1.48 & 1.13 \\
\hline $\mathrm{Na}$ & - & - & 0.04 & - & 0.03 & - & 0.03 & 0.02 & - & - \\
\hline Total & 1.61 & 0.25 & 1.44 & 1.38 & 1.27 & 0.25 & 1.14 & 1.29 & 1.53 & 1.23 \\
\hline
\end{tabular}

Note: Total iron as $\mathrm{Fe}_{2} \mathrm{O}_{3}$ for celadonite and mixtures of celadonite and nontronite and $\mathrm{FeO}$ for saponite; dash indicates not detected. 


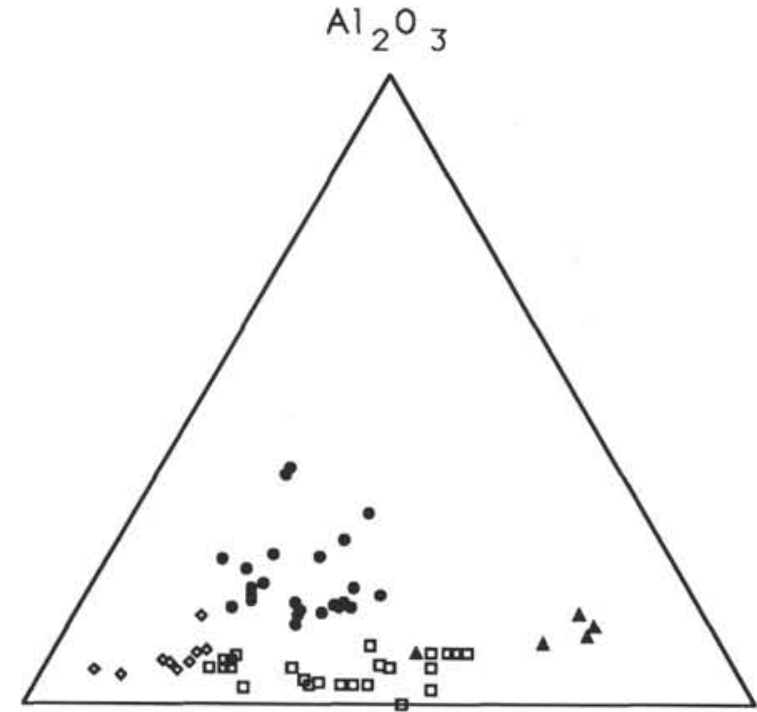

$\mathrm{Fe}_{2} \mathrm{O}_{3}$

$\mathrm{MgO}$

Figure 1. $\mathrm{Al}_{2} \mathrm{O}_{3}-\mathrm{Fe}_{2} \mathrm{O}_{3}-\mathrm{MgO}$ molar proportions of the clay minerals. Squares, celadonite; circles, celadonite-nontronite mixtures; triangles, saponite; diamonds, celadonite-Fe-oxyhydroxide mixtures.

Table 2. Representative calcite analyses, Hole 765D.

\begin{tabular}{ccccc}
\hline $\begin{array}{l}\text { Core, section, } \\
\text { interval (cm) }\end{array}$ & $\begin{array}{c}1 \mathrm{R}-2,30-34 \\
\text { (vein) }\end{array}$ & $\begin{array}{c}\text { 2R-2, 47-53 } \\
\text { (vein) }\end{array}$ & $\begin{array}{c}7 \mathrm{R}-3,0-7 \\
\text { (vesicle) }\end{array}$ & $\begin{array}{c}25 \mathrm{R}-1,34-41 \\
\text { (vein) }\end{array}$ \\
\hline $\mathrm{Na}_{2} \mathrm{O}$ & 0.03 & - & 0.04 & 0.03 \\
$\mathrm{CaO}$ & 58.47 & 60.19 & 56.50 & 60.8 \\
$\mathrm{FeO}$ & 0.03 & 0.09 & 0.04 & 0.03 \\
$\mathrm{MnO}$ & 0.04 & 0.28 & 0.2 & 0.02 \\
$\mathrm{MgO}$ & 1.01 & 0.23 & 0.08 & 0.58 \\
Total & 59.58 & 60.80 & 56.86 & 61.5 \\
\hline
\end{tabular}

Note: Total iron as $\mathrm{FeO} ;-=$ not detected.

fractures. Cleavages are slightly bent in many calcite veins. Calcite is pure in composition with $<1 \mathrm{~mol} \% \mathrm{Mg}$ and trace amounts of $\mathrm{MnO}$ (Table 3).

\section{Fe-oxyhydroxides}

Fe-oxyhydroxides occur as groundmass-replacing and voidfilling phases throughout the core. The concentration of Fe-oxyhydroxides, particularly in the orange halos, makes many samples appear oxidized. Fe-oxyhydroxides are generally amorphous; however, goethite has been identified by XRD in two veins where it is associated with quartz and celadonite.

\section{Alteration Products of Plagioclase}

Patchy zoning in igneous plagioclase reflects partial alteration to assemblages of albite, analcime, and $\mathrm{Ca}-\mathrm{Na}$ zeolites (Table 2 and Fig. 2). The degree of replacement is generally $<10 \%$, but may be as great as $50 \%$ and is concentrated in the cores and along fractures of individual grains. In Sample 123-765D-2R-3, 122$127 \mathrm{~cm}$, plagioclase has been completely altered to a complex assemblage of $\mathrm{K}$-feldspar, natrolite, and albite (Fig. 2D). The alteration assemblage is consistent within individual samples and is generally not associated with the alteration halos.

\section{Alteration Patterns}

The basement section recovered at Hole $765 \mathrm{D}$ is characterized by nonpervasive alteration, which varies in intensity within and between individual lithologic units. Well-developed orange and green alteration halos locally parallel fracture surfaces and extend several centimeters into the surrounding rock (see Shipboard Scientific Party, 1990, figs. 100 and 101). The adjacent groundmass is greenish gray to dark gray and does not contain clay minerals. Fresh volcanic glass is locally preserved throughout the core.

Glassy pillow margins and hyaloclastite have been altered to assemblages of smectite, analcime, and phillipsite. Interpillow interstices are filled with altered hyaloclastite or calcite. The mesostasis has been altered to celadonite, Fe-oxyhydroxides, mixtures of celadonite and nontronite, saponite, and rare zeolites. Clay minerals locally line fractures in plagioclase and clinopyroxene. Massive flows have been altered to the same assemblages as pillows, but are generally less altered than pillows. Tectonic breccias within both pillows and massive flows are cemented with 1- to 2-cm-thick veins of calcite (see Shipboard Scientific Party, 1990, fig. 92).

Several stages of secondary mineral deposition can be recognized on the basis of crosscutting relationships and precipitation sequences in filled voids. The following generalization may be made: (1) Fe-oxyhydroxides mixed with celadonite line fractures, (2) celadonite $\pm \mathrm{Fe}$-oxyhydroxides or calcite \pm Fe-oxyhydroxides fills fractures, (3) calcite veins generally crosscut clay veins (where clay minerals and calcite occur together in a vein, calcite is the last phase to precipitate), and (4) successive layers of sparry calcite, which grow perpendicular to the fracture surface, indicate several stages of deposition.

Alteration halos, a few millimeters to a few centimeters wide, rim many fractures throughout the hole (Table 4 and Fig. 3). Color zonations within these halos may be simple or complex and reflect the relative abundance of celadonite and Fe-oxyhydroxides that replace the groundmass and fill voids. The general sequence of zones away from a fracture is as follows:

1. Orange: Fe-oxyhydroxides and celadonite fill voids and replace the mesostasis; celadonite generally lines voids, followed by Fe-oxyhydroxides; a narrow zone of Fe-oxyhydroxides is directly adjacent to the fracture surface in many samples.

2. Green: celadonite and minor Fe-oxyhydroxides occur in the groundmass; Fe-oxyhydroxides or celadonite generally lines voids.

The boundary between these zones is gradational; all boundaries with the adjacent rock are sharp and dark green to black. The groundmass adjacent to the halos is "fresh" in that it contains no clay minerals and only minor Fe-oxyhydroxides; however, plagioclase generally has been partially altered to albite and/or Ca$\mathrm{Na}$ zeolites.

The replacement products of plagioclase are generally consistent within individual samples such that plagioclase within halos has been altered to the same assemblages as in the adjacent fresh rock. For example, plagioclase in Sample 123-765D-2R-2, 47-53 $\mathrm{cm}$, has been partially altered to chabazite and albite within its orange halo and adjacent rock. In Sample 123-765D-25R-1, 34 $41 \mathrm{~cm}$, however, plagioclase has been altered to analcime and albite within the orange halo and to mesolite in the adjacent fresh rock (Fig. 2B).

During the preliminary shipboard study of Hole $765 \mathrm{D}$, the scientists identified an alteration boundary at a sub-basement 
Table 3. Representative analyses of plagioclase and its alteration products, Hole 765D.

\begin{tabular}{|c|c|c|c|c|c|c|c|c|c|c|}
\hline \multirow{3}{*}{$\begin{array}{c}\text { Core, section, } \\
\text { interval }(\mathrm{cm}) \\
\text { Mineral }\end{array}$} & \multicolumn{3}{|c|}{$2 R-3,122-127$} & \multicolumn{2}{|c|}{$7 R-3,0-7$} & \multicolumn{5}{|c|}{$25 \mathrm{R}-1,34-41$} \\
\hline & K-feldspar & Albite & Natrolite & $\begin{array}{c}\text { Igneous } \\
\text { plagioclase }\end{array}$ & Albite & $\begin{array}{c}\begin{array}{c}\text { Igneous } \\
\text { plagioclase }\end{array} \\
\end{array}$ & Analcime & Albite & $\begin{array}{c}\begin{array}{c}\text { Igneous } \\
\text { plagioclase }\end{array} \\
\end{array}$ & Mesolite \\
\hline & \multicolumn{3}{|c|}{ (same phenocryst) } & \multicolumn{2}{|c|}{$\begin{array}{l}\text { (same lath in green } \\
\text { zone) }\end{array}$} & \multicolumn{3}{|c|}{ (same lath in orange zone) } & \multicolumn{2}{|c|}{$\begin{array}{l}\text { (same lath in } \\
\text { groundmass with no } \\
\text { clay minerals) }\end{array}$} \\
\hline \multicolumn{11}{|c|}{ Major element composition (wt\%) } \\
\hline $\mathrm{SiO}_{2}$ & 66.14 & 70.56 & 49.13 & 50.86 & 70.38 & 55.63 & 60.20 & 70.96 & 55.11 & 43.28 \\
\hline $\mathrm{Al}_{2} \mathrm{O}_{3}$ & 17.84 & 18.81 & 27.57 & 29.38 & 19.22 & 27.10 & 22.81 & 19.88 & 27.155 & 27.47 \\
\hline $\mathrm{FeO}^{\mathrm{T}}$ & 0.12 & - & 0.14 & 0.62 & 0.09 & 0.96 & 0.09 & 0.19 & 0.905 & 0.02 \\
\hline $\mathrm{MgO}$ & 0.02 & - & 0.04 & 0.33 & 0.03 & 0.10 & - & - & 0.098 & - \\
\hline $\mathrm{CaO}$ & 0.04 & 0.01 & 2.83 & 13.49 & 0.19 & 10.30 & 0.09 & 0.57 & 10.839 & 9.90 \\
\hline $\mathrm{Na}_{2} \mathrm{O}$ & 0.09 & 11.72 & 5.96 & 3.6 & 11.01 & 5.55 & 9.75 & 10.59 & 5.282 & 2.81 \\
\hline $\mathrm{K}_{2} \mathrm{O}$ & 15.52 & 0.04 & - & - & - & 0.06 & - & - & 0.031 & - \\
\hline Total & 99.76 & 101.14 & 85.66 & 98.28 & 100.92 & 99.70 & 92.85 & 102.19 & 99.422 & 83.49 \\
\hline \multicolumn{11}{|c|}{ Cation proportions } \\
\hline $\mathrm{Si}$ & 3.08 & 3.05 & 25.2 & 2.36 & 3.07 & 2.51 & 2.48 & 3.07 & 2.5 & 8.75 \\
\hline $\mathrm{Al}$ & 0.98 & 0.96 & 16.67 & 1.6 & 0.99 & 1.45 & 1.10 & 1.01 & 1.46 & 6.54 \\
\hline $\mathrm{Fe}$ & - & - & 0.06 & 0.02 & - & 0.04 & - & - & 0.03 & - \\
\hline $\mathrm{Mg}$ & - & - & - & - & - & - & - & - & - & - \\
\hline $\mathrm{Ca}$ & - & - & 1.55 & 0.67 & - & 0.50 & - & 0.03 & 0.53 & 2.14 \\
\hline $\mathrm{Na}$ & - & 0.98 & 5.93 & 0.32 & 0.93 & 0.49 & 0.78 & 0.89 & 0.46 & 1.10 \\
\hline $\mathrm{K}$ & 0.92 & - & - & - & - & - & - & - & - & - \\
\hline Total & 4.98 & 4.99 & 47.86 & 4.97 & 4.99 & 4.99 & 4.36 & - & 4.98 & 18.53 \\
\hline 0 & 8 & 8 & 80 & 8 & 8 & 8 & 7 & 8 & 8 & 30 \\
\hline Analcime & 0 & 0 & & 0.67 & 0.01 & 0.5 & & 0.03 & 0.53 & \\
\hline Albite & 0 & 1.00 & & 0.33 & 0.99 & 0.5 & & 0.97 & 0.47 & \\
\hline Orthoclase & 1.00 & 0 & & - & - & - & & 0 & 0 & \\
\hline
\end{tabular}

Note: Total iron as $\mathrm{FeO}$; dash indicates not detected.

depth of approximately $1075 \mathrm{~m}$ (Core 123-765D-14R) based on the disappearance of celadonite and a corresponding decrease in $\mathrm{K}_{2} \mathrm{O}$ bulk-rock contents. This study has shown that there is no vertical zonation of secondary minerals and that the lower $\mathrm{K}_{2} \mathrm{O}$ bulk-rock contents reflect a decrease in the abundance of celadonite, rather than its disappearance.

\section{Geochemistry Techniques}

Five samples with well-developed alteration halos and the adjacent rock were chosen for chemical analysis. Major element and trace element data were obtained on 400-mg samples using direct-current plasma emission spectrometry at Lamont-Doherty Geological Observatory (Table 5). Details of the technique are reported in Klein et al. (1991) and Plank and Ludden (this volume). The precision for major elements is better than $1 \%$ and that of trace elements is better than $2 \%$.

The $\delta^{18} \mathrm{O}$ contents of bulk rocks were determined using a nuclide 6-60-RMS triple collector mass spectrometer at the Université de Montréal. Oxygen was extracted by reaction with $\mathrm{BrF}_{5}$ at $680^{\circ}$ to $700^{\circ} \mathrm{C}$ (Clayton and Mayeda, 1963). All results are reported vs. V-SMOW (Baertschi, 1976). Analytical precision is $\pm 0.2 \%$.

\section{General Geochemical Characteristics}

The basalts recovered at Site 765 are relatively evolved $(\mathrm{FeO} * / \mathrm{MgO}=1-2)$ normal mid-ocean ridge tholeiites (Shipboard Scientific Party, 1990) that are highly depleted in incompatible trace elements (Ludden and Dionne, this volume). Glass and whole-rock samples display a negative correlation between $\mathrm{FeO} * / \mathrm{MgO}$ ratios and $\mathrm{TiO}_{2}$ content which may reflect either mantle source heterogeneity (Ishiwatari, this volume) or the separation of melts from a heterogeneous mantle at different pressures (Ludden and Dionne, this volume). High $\mathrm{CaO}$ and low $\mathrm{Na}_{2}$ con- tents at a given $\mathrm{MgO}$ value relative to other mid-ocean ridge tholeiites are thought to reflect a high degree of partial melting (cf. Klein and Langmuir, 1987). The highly depleted trace element content of the Hole 765D samples is also characteristic of basalts derived from a high degree of partial melting.

Downhole primary geochemical trends show cyclic variations in the abundance of $\mathrm{TiO}_{2}, \mathrm{Zr}$, and other trace elements that are not affected by alteration. $\mathrm{TiO}_{2} / \mathrm{Zr}$ ratios remain relatively constant through the basement section, indicating that cyclic variation may reflect the influx of different batches of magma that have undergone variable degrees of fractionation (Ludden and Dionne, this volume).

The primary $\mathrm{K}_{2} \mathrm{O}$ contents of the lavas, based on microprobe analyses of volcanic glass, vary from 0.05 to $0.1 \mathrm{wt} \%$ in low- $\mathrm{TiO}_{2}$ glasses to as much as $0.23 \%$ in high- $\mathrm{TiO}_{2}$ glasses. The least-altered whole rocks have a $\mathrm{K}_{2} \mathrm{O}$ content between 0.1 and 0.25 wt\% and $\mathrm{Rb}$ contents $\leq 1 \mathrm{ppm}$. $\mathrm{Sr}$ and $\mathrm{Ba}$ values are approximately 80 to $100 \mathrm{ppm}$ and 5 to $8 \mathrm{ppm}$, respectively, in the freshest wholerock samples.

\section{Chemical Effects of Alteration}

Bulk compositional changes associated with alteration were investigated using the downhole geochemical trends of the shipboard X-ray-fluorescence data and from selected samples with well-developed alteration halos. Whole-rock samples throughout the hole are significantly enriched in $\mathrm{K}_{2} \mathrm{O}$ and $\mathrm{Rb}$. Downhole plots of these elements show that the upper $140 \mathrm{~m}$ of the hole is 5 to 10 times more enriched than the lower $120 \mathrm{~m}$ of the hole (Fig. 4). This decrease in alkali content at a sub-basement depth of approximately $1075 \mathrm{~m}$ was attributed to the disappearance of celadonite (Shipboard Scientific Party, 1990). Additional mineralogical data (this study), however, have shown that celadonite occurs throughout the core and that the decrease in $\mathrm{K}_{2}$ and $\mathrm{Rb}$ 


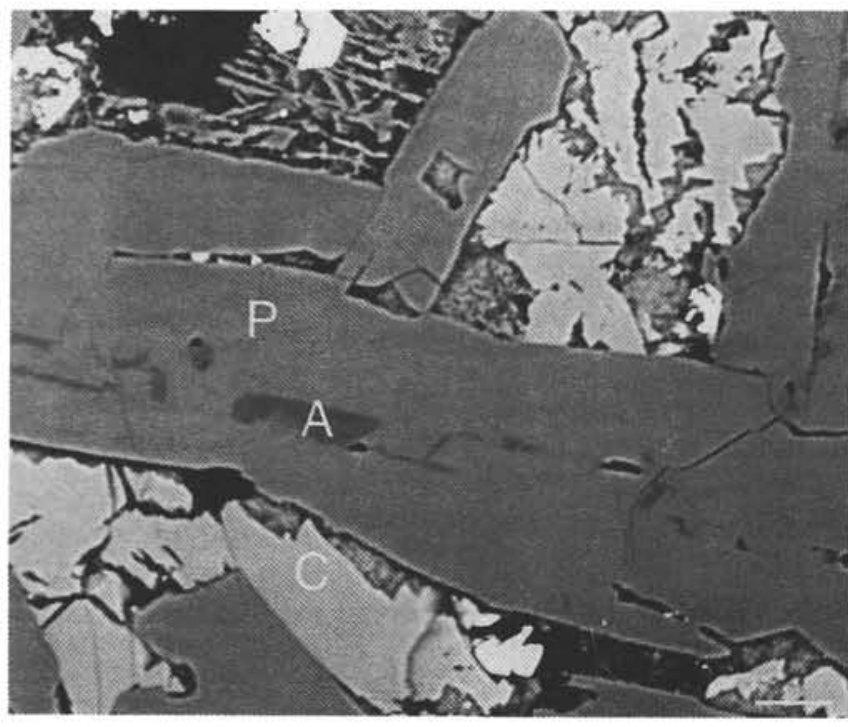

A

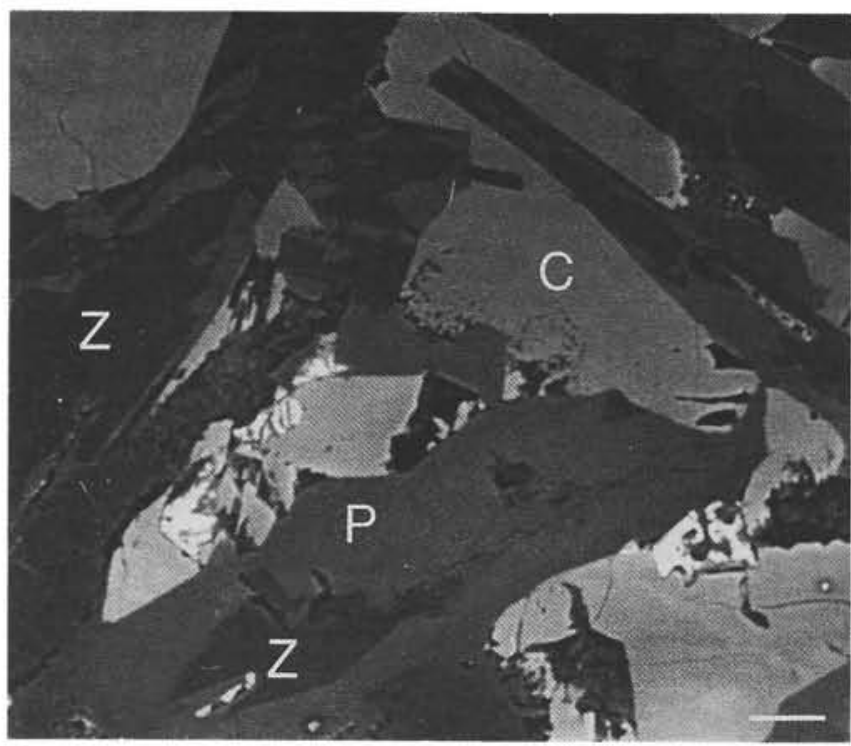

C

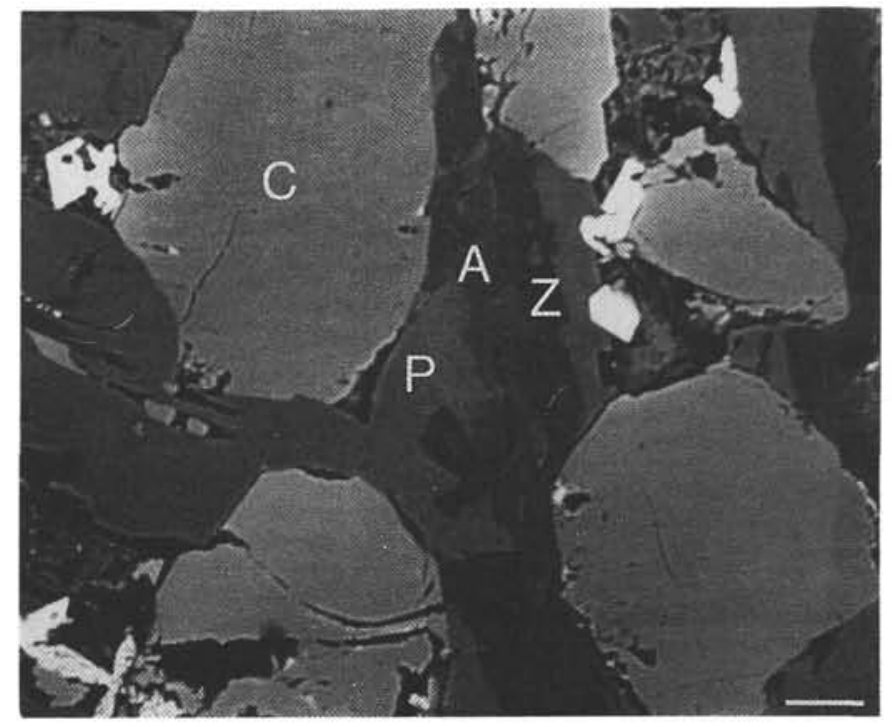

B

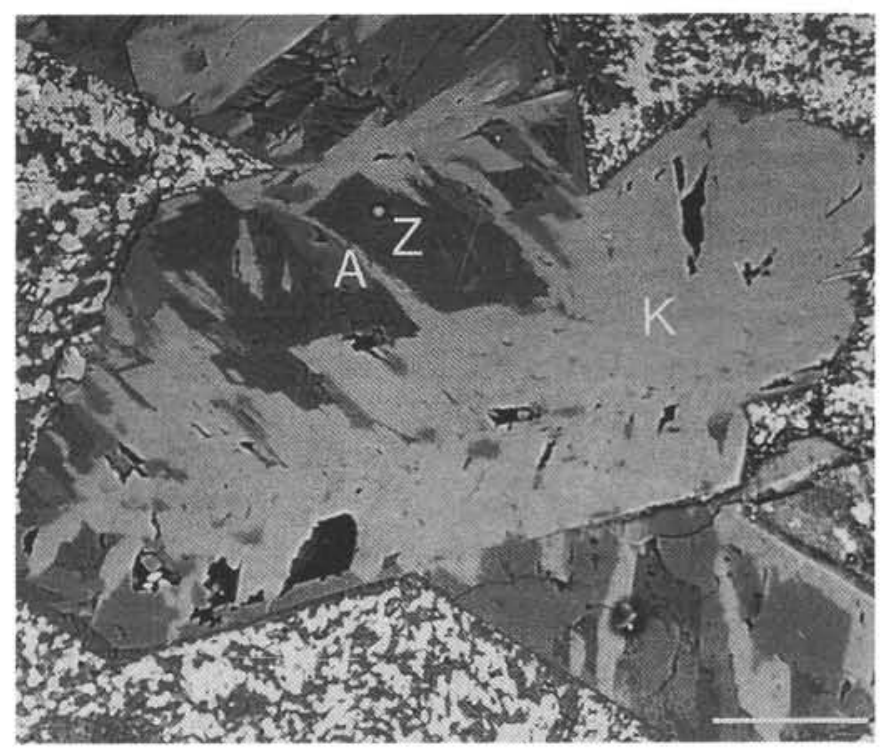

D

Figure 2. Backscattered electron images (BEI) of plagioclase showing compositional variation within individual grains. Lighter grays in BEI indicate higher average atomic element compositions, corresponding to igneous plagioclase (An50-60). The variation in contrast among the samples is due to photographic conditions and does not reflect compositional differences. A. Green zone: igneous plagioclase partially altered to albite (Sample 123-765D-7R-3, 0-7 cm). B. Orange zone: plagioclase altered to albite and analcime (Sample 123-765D-25R-1,34-41 cm); C. Fresh rock: plagioclase partially altered to mesolite (Sample 123-765D-25R-1, $34-41 \mathrm{~cm}$ ). D. Igneous plagioclase phenocryst completely altered to K-feldspar, natrolite, and albite (Sample 123-765D-2R-3, 122-127 cm). Abbreviations: P= igneous plagioclase; $\mathrm{A}=$ albite; $\mathrm{Z}=$ zeolite; $\mathrm{K}=\mathrm{K}$-feldspar; $\mathrm{C}=$ clinopyroxene. Scale bar $=100 \mu \mathrm{m}$.

contents corresponds to a decrease in the degree of alteration, with the alteration in the shallower basement more pervasive and uniform.

To evaluate what elements are mobilized during the development of the alteration halos, we compared the compositions of alteration halos and their adjacent fresh rock in five samples. Qualitative fluxes were calculated by dividing the compositions of the alteration halos by those of the adjacent fresh rock (Table 6). This method indicates general trends of enrichment and depletion, but does not account for accumulation/dilution effects.

$\mathrm{K}_{2} \mathrm{O}$ and, to a lesser extent, $\mathrm{Fe}_{2} \mathrm{O}_{3}$ are enriched in both the orange and green halos. $\mathrm{K}_{2} \mathrm{O}$ enrichment, due to the presence of celadonite, is generally comparable in both the orange and green zones. In Sample 123-765D-23R-2, 72-76 cm, however, $\mathrm{K}_{2} \mathrm{O}$ enrichment is greater in the green zone than in the orange zone and may reflect a dilution caused by the high $\mathrm{Fe}_{2} \mathrm{O}_{3}$ content in the orange zone or a greater concentration of celadonite in the green zone. The variation in the magnitude of $\mathrm{K}_{2} \mathrm{O}$ enrichment among the samples is probably due to the $\mathrm{K}_{2} \mathrm{O}$ content of the fresh rock, which was used in the flux calculation. For example, the $\mathrm{K}_{2} \mathrm{O}$ content of the fresh portion of Sample 123-765D-9R-1, 82-90 cm, is lower than might be estimated from the $\mathrm{TiO}_{2}-\mathrm{K}_{2} \mathrm{O}$ correlation for glass samples (i.e., samples with $1.4 \mathrm{wt} \% \mathrm{TiO}_{2}$ have $0.12 \mathrm{wt} \%$ $\mathrm{K}_{2} \mathrm{O}$ ). If the $\mathrm{K}_{2} \mathrm{O}$ content predicted from the $\mathrm{TiO}_{2}-\mathrm{K}_{2} \mathrm{O}$ correlation 
Table 4. Distribution of alteration halos, Hole 765D.

\begin{tabular}{|c|c|c|c|c|c|}
\hline \multirow{2}{*}{$\begin{array}{l}\text { Core, section, } \\
\text { interval }(\mathrm{cm})\end{array}$} & \multirow[b]{2}{*}{ Vein type } & \multicolumn{2}{|c|}{ Alteration halo } & \multicolumn{2}{|c|}{$\begin{array}{l}\text { Adjacent } \\
\text { groundmass }\end{array}$} \\
\hline & & Orange & Green & Altered & Fresh \\
\hline $2 \mathrm{R}-2,47-53$ & Calcite + celadonite & $\mathrm{X}$ & & $\mathrm{x}$ & \\
\hline $5 R-3,110-116$ & Celadonite $+\mathrm{Fe}$-oxyhydroxides & $\mathrm{x}$ & & $\mathrm{x}$ & \\
\hline $7 R-2,112-117$ & Celadonite $+\mathrm{Fe}$-oxyhydroxides & $\mathrm{x}$ & $\mathrm{X}$ & & $\mathrm{x}$ \\
\hline $7 \mathrm{R}-3,0-7$ & Fe-oxyhydroxides & $\mathrm{x}$ & & & $\mathrm{x}$ \\
\hline $9 \mathrm{R}-1,82-90$ & Open fractures & $\mathrm{x}$ & $\mathrm{x}$ & & $\mathrm{x}$ \\
\hline $19 \mathrm{R}-1,115-121$ & Fe-oxyhydroxides + celadonite & & $\mathrm{x}$ & & $\mathrm{x}$ \\
\hline $23 \mathrm{R}-2,72-76$ & Open fractures & $\mathrm{x}$ & $\mathrm{x}$ & & $\mathrm{x}$ \\
\hline $24 \mathrm{R}-2,81-86$ & Fe-oxyhydroxides + celadonite & & $\mathrm{x}$ & $\mathrm{X}$ & \\
\hline $25 \mathrm{R}-1,34-41$ & Calcite & $\mathrm{x}$ & & & $\mathrm{X}$ \\
\hline $27 \mathrm{R}-3,27-36$ & & $\mathrm{x}$ & & $\mathrm{x}$ & \\
\hline
\end{tabular}

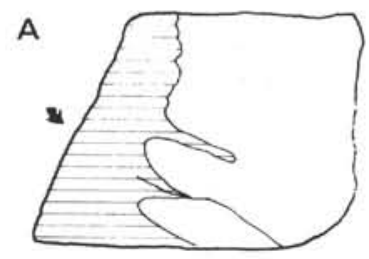

B
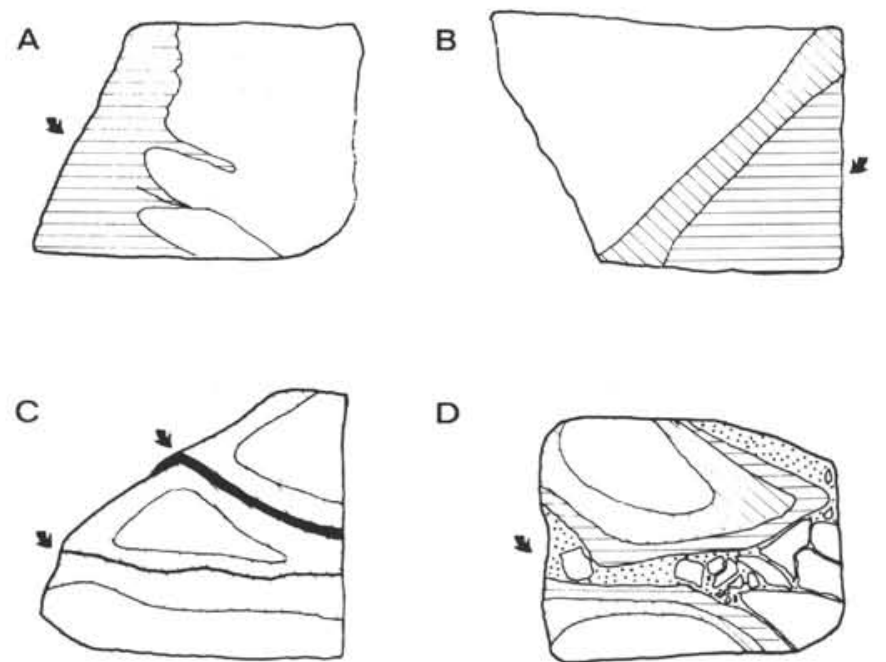

D

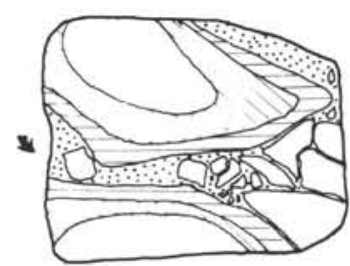

$1 \mathrm{~cm}$

Figure 3. Sketches of typical alteration halos adjacent to filled and open fractures. A. Orange halo adjacent to an open fracture (Sample 123-765D-7R-3, $0-7 \mathrm{~cm}$ ). B. Orange and green halo adjacent to an open fracture (Sample 123-765D-9R-1, 82-90 cm). C. Green halo adjacent to an Fe-oxyhydroxide vein (Sample 123-765D-19R-1, 115-121 cm). D. Orange and green halo adjacent to a calcite vein (Sample 123-765D-25R-1, 34-41 cm). Horizontal lines, orange halo; diagonal lines, green halo; dots, calcite vein. Arrows point to the fracture surface.

value is used in the flux calculation, the calculated $\mathrm{K}_{2} \mathrm{O}$ flux of Sample 123-765D-9R-1, 82-90 cm, is comparable to those of the other samples. More precise measurements of the alkalis by isotope dilution are in progress and will allow for better estimates of alkali mobilization. The correlation of $\mathrm{Rb}$ and $\mathrm{K}_{2} \mathrm{O}$ (Fig. 4) suggests that $\mathrm{Rb}$ is also enriched in both the orange and green zones. Preferential removal of $\mathrm{Rb}$ from seawater relative to $\mathrm{K}$ during celadonite and smectite precipitation (Staudigel et al., 1981) indicates that $\mathrm{Rb}$ may be more enriched in the alteration halos than $\mathrm{K}_{2} \mathrm{O}$. $\mathrm{Fe}_{2} \mathrm{O}_{3}$ is most enriched in the orange zones, where $\mathrm{Fe}$-oxyhydroxides are most abundant (e.g., Sample 123$765 \mathrm{D}-23 \mathrm{R}-2,72-76 \mathrm{~cm}$ ). A decrease in $\mathrm{MgO}$ in the alteration halos of Samples 123-765D-9R-1, 82-90 cm, 123-765D-7R-3, $0-7 \mathrm{~cm}$, and $123-765 \mathrm{D}-23 \mathrm{R}-2,72-76 \mathrm{~cm}$, may reflect alteration of the mesostasis to celadonite and $\mathrm{Fe}$-oxyhydroxides, whereas a decrease in $\mathrm{CaO}$ in Samples 123-765D-19R-1, 115-121 cm, and 123-765D-25R-1, 34-41 cm, may reflect the partial replacement of plagioclase by analcime and albite.

The alteration halos and their adjacent fresh rock are enriched in ${ }^{18} \mathrm{O}$ relative to that of fresh mid-oceanic ridge basalts (MORBs;
$5.8 \%$ ) by $2 \%$ to $3 \%$ throughout Hole $765 \mathrm{D}$ (Table 5 ), suggesting that the lava sequence reacted with seawater at low temperatures (e.g., Muehlenbachs, 1979). The $\delta^{18} \mathrm{O}$ content of each alteration halo is generally within $\pm 0.1 \%$ of that of the adjacent fresh rock, showing that even the freshest rocks have reacted with seawater. Trace amounts of clay minerals along grain boundaries and/or the partial zeolitization of plagioclase probably contributed to the increase in $\delta^{18} \mathrm{O}$ in the freshest samples. The variation in $\delta^{18} \mathrm{O}$ content among the samples may reflect variation in the relative abundance of secondary minerals in the groundmass or small fluctuations in temperature. Similar variations within and among samples have been documented in other DSDP/ODP cores that underwent low-temperature alteration (e.g., Sites 396 and 417, Böhlke et al., 1984).

\section{DISCUSSION}

\section{Development of Alteration Halos}

The alteration patterns at Hole $765 \mathrm{D}$ are similar to those documented for most other DSDP/ODP shallow basement cores (e.g., Sites 417, 418, 396; see Honnorez, 1981). The secondary mineralogy and associated chemical fluxes of these cores show that the upper few tens to hundreds of meters of oceanic basement has been altered by oxygenated seawater at low temperatures (e.g., Alt and Honnorez, 1984). The thickness and pervasiveness of this oxidative alteration, generally referred to as seafloor weathering, is dependent upon the duration of open circulation of cold seawater and, thus, the rate and nature of sedimentation (Gillis and Robinson, 1988).

Mineralogical zonations adjacent to fractures have been recognized in many DSDP cores (e.g., Hole 396B; Seyfried et al., 1978; Andrews, 1980; Böhlke et al., 1980; Adamson and Richards, 1990). Scientists generally think that these zonations form as oxygenated seawater migrates inward along grain boundaries and reacts with the basalt. Initially, basaltic $\mathrm{Fe}$ is oxidized and leached from the rock, forming Fe collides (Seyfried et al., 1978). Some $\mathrm{Fe}$ precipitates as $\mathrm{Fe}$-oxyhydroxides, liberating $\mathrm{H}^{+}$and inhibiting the formation of Mg-saponite (Bass, 1976; Seyfried et al., 1978). If sufficient $\mathrm{K}, \mathrm{Si}$, and $\mathrm{Al}$ are available, some $\mathrm{Fe}$ floccules act as the precursor for celadonite precipitation (Wise and Eugster, 1964; Seyfried et al., 1978). As seawater continues to diffuse inward, it is eventually depleted in oxygen; the formation of Fe-oxyhydroxides is inhibited and saponite is precipitated. These evolved seawater-derived solutions, with high alkali cation to $\mathrm{H}^{+}$ion ratios, would also lead to the replacement of plagioclase by zeolites (Hey, 1966; Barrows, 1980). Increased $\mathrm{Na}^{+} / \mathrm{K}^{+}$ratios in these solutions, due to the precipitation of celadonite, may favor the formation of analcime and other Na-rich zeolites (e.g., chabazite and natrolite) (Alt and Honnorez, 1984). With a continuous supply of oxygenated seawater, zones of Fe-oxyhydroxides 
Table 5. Major and trace element composition of representative alteration halos and adjacent groundmass, Hole 756D.

\begin{tabular}{|c|c|c|c|c|c|c|c|c|c|c|c|c|}
\hline \multirow{2}{*}{$\begin{array}{l}\text { Core, section, } \\
\text { interval }(\mathrm{cm}) \\
\text { Zone }\end{array}$} & \multicolumn{2}{|c|}{$7 \mathrm{R}-3,0-7$} & \multicolumn{3}{|c|}{$9 \mathrm{R}-1,82-90$} & \multicolumn{2}{|c|}{$19 \mathrm{R}-1,115-121$} & \multicolumn{3}{|c|}{$23 R-2,72-76$} & \multicolumn{2}{|c|}{$25 \mathrm{R}-1,34-41$} \\
\hline & Fresh & Orange & Fresh & Green & Orange & Fresh & Green & Fresh & Orange & Green & Fresh & Orange \\
\hline \multicolumn{13}{|c|}{ Major element composition (wt\%) } \\
\hline $\mathrm{SiO}_{2}$ & 50.55 & 49.52 & 51.41 & 50.9 & 50.16 & 52.33 & 51.25 & 51.46 & 47.71 & 51.36 & 51.16 & 50.59 \\
\hline $\mathrm{TiO}_{2}$ & 1.41 & 1.26 & 1.41 & 1.33 & 1.32 & 1.59 & 1.56 & 1.65 & 1.60 & 1.67 & 1.49 & 1.50 \\
\hline $\mathrm{Al}_{2} \mathrm{O}_{3}$ & 15.53 & 14.01 & 15.32 & 14.18 & 14.07 & 14.55 & 14.07 & 14.89 & 13.96 & 14.98 & 14.99 & 13.43 \\
\hline $\mathrm{Fe}_{2} \mathrm{O}_{3} \mathrm{~T}$ & 8.72 & 13.77 & 9.71 & 12.14 & 13.58 & 9.56 & 11.8 & 9.70 & 17.19 & 11.13 & 10.04 & 13.57 \\
\hline $\mathrm{MgO}$ & 6.82 & 6.56 & 8.13 & 6.80 & 6.54 & 6.85 & 6.51 & 7.33 & 5.77 & 6.10 & 6.98 & 6.79 \\
\hline $\mathrm{MnO}$ & 0.16 & 0.19 & 0.157 & 0.19 & 0.19 & 0.174 & 0.182 & 0.18 & 0.23 & 0.16 & 0.20 & 0.22 \\
\hline $\mathrm{CaO}$ & 13.61 & 11.42 & 11.6 & 11.06 & 11.3 & 12.48 & 10.75 & 11.64 & 10.94 & 10.84 & 11.41 & 9.87 \\
\hline $\mathrm{Na}_{2} \mathrm{O}$ & 2.85 & 2.46 & 2.61 & 2.38 & 2.36 & 3.05 & 2.87 & 2.87 & 2.81 & 2.89 & 3.53 & 3.82 \\
\hline $\mathrm{K}_{2} \mathrm{O}$ & 0.40 & 0.82 & 0.04 & 0.77 & 0.73 & 0.28 & 0.819 & 0.12 & 0.38 & 0.83 & 0.28 & 0.46 \\
\hline $\mathrm{P}_{2} \mathrm{O}_{5}$ & 0.11 & 0.10 & 0.11 & 0.10 & 0.10 & 0.132 & 0.126 & .14 & 0.15 & 0.14 & 0.13 & 0.13 \\
\hline Total & 100.16 & 100.10 & 100.50 & 99.86 & 100.40 & 100.00 & 99.94 & 99.98 & 100.74 & 100.11 & 100.21 & 100.38 \\
\hline LOI & 2.41 & 1.48 & 2.80 & 1.23 & 1.43 & 0.97 & 1.46 & 1.67 & 1.65 & 1.72 & 2.77 & 2.59 \\
\hline \multicolumn{13}{|c|}{ Trace element composition (ppm) } \\
\hline $\mathrm{Sr}$ & 90.4 & 79.3 & 90.1 & 79 & 79.2 & 86.6 & 81.5 & 85.9 & 85.4 & 87.0 & 190.7 & 81.4 \\
\hline $\mathrm{Ba}$ & 4.7 & 4.7 & 5.1 & 4.5 & 4.8 & 6.9 & 5.3 & 5.4 & 8.7 & 8.1 & 8.9 & 8.2 \\
\hline $\mathrm{Zr}$ & 79.9 & 74.4 & 81.9 & 75.9 & 77 & 94.3 & 98.7 & 98.8 & 99.3 & 105.0 & 86 & 92 \\
\hline $\mathrm{Y}$ & 35.8 & 33.9 & 32.5 & 33 & 35.1 & 41.8 & 35.3 & 40.7 & 43.9 & 36.9 & 38.2 & 35.9 \\
\hline $\mathrm{Cu}$ & 33.2 & 43.2 & 90.5 & 80.6 & 93.2 & 33 & 41.3 & 199.4 & 41.0 & 26.8 & 32.3 & 41.7 \\
\hline $\mathrm{Ni}$ & 118.3 & 76.7 & 118.7 & 106.4 & 65.8 & 79.4 & 69.9 & 75.1 & 68.7 & 57.6 & 67.5 & 71 \\
\hline $\mathrm{SC}$ & 47.4 & 43.4 & 47.4 & 43.3 & 43.1 & 44.9 & 44.5 & 46.7 & 45.0 & 45.6 & 45.5 & 45.8 \\
\hline $\mathrm{Zn}$ & 89.9 & 94.1 & 75.7 & 82.4 & 89.9 & 74.6 & 85 & 110.4 & 107.6 & 97.1 & 81.7 & 86.4 \\
\hline V & 339.8 & 351.2 & 357.3 & 339.6 & 345.3 & 338.1 & 351.5 & 342.6 & 425.5 & 348.5 & 315.5 & 380.8 \\
\hline $\mathrm{Cr}$ & 298.7 & 280.1 & 267.5 & 244.4 & 252.1 & 200.3 & 224.0 & 190.9 & 173.4 & 73.49 & 195.5 & 225.2 \\
\hline$\delta^{18} \mathrm{O}$ & 8.6 & 8.6 & n.d. & n.d. & n.d. & 8.2 & 8.3 & n.d. & n.d. & n.d. & 9.7 & 10.0 \\
\hline
\end{tabular}

Note: Total iron as $\mathrm{Fe}_{2} \mathrm{O}_{3}$; n.d. = not determined; $\mathrm{LOI}=$ loss on ignition.

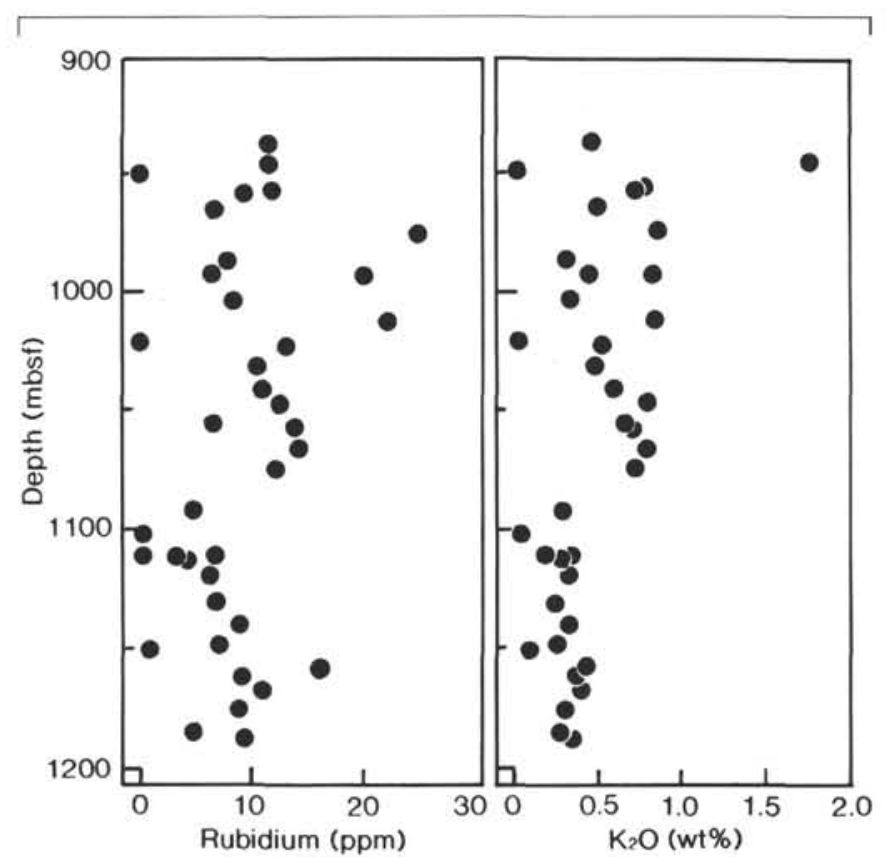

Figure 4. Depth profile of $\mathrm{K}_{2} \mathrm{O}$ and $\mathrm{Rb}$ contents of the basement section at Hole $765 \mathrm{D}$.

and celadonite migrate inward, overprinting previously formed minerals (Andrews, 1980).

Alteration halos identified in very young volcanic rocks, generally referred to as black halos, are thought represent the incipient stage of the mineralogical zonations observed in old oceanic crust (Honnorez, 1981; Adamson and Richards, 1990). Secondary minerals associated with black halos fill preexisting voids; however, these halos may occur up to several centimeters from a fracture and show no petrographic evidence for the migration of fluids between the fracture and the halo. The source of the altering fluids is thought to be a mixture of seawater and low-temperature hydrothermal fluids (Adamson and Richards, 1990).

Mineralogic zonation within the alteration halos at Site 765 is similar to that in other DSDP cores; however, saponite is scarce in the groundmass of the volcanic rocks at Hole 765D. Where present, saponite occurs in the groundmass adjacent to alteration halos mixed with celadonite and/or Fe-oxyhydroxides. The association of saponite with celadonite and Fe-oxyhydroxides implies that an oxidative alteration front migrated inward from the fracture and overprinted earlier alteration. The scarcity of saponite and the absence of clay minerals in the interior of most of the core, particularly in the lower $120 \mathrm{~m}$, imply that the volcanic rocks at Site 765 were sealed early in its history and that the duration of seawater-rock interaction was short-lived.

Experimental studies and $\delta^{18} \mathrm{O}$ contents of celadonite and nontronite from other areas indicate that temperatures during formation of the alteration halos were $<40^{\circ} \mathrm{C}$ (Seyfried et al., 1978; Stakes and O'Neill, 1982; Böhlke et al., 1984). The O-isotopic content of the altered whole rocks at Hole 765D is comparable to that of basalts altered at low temperatures elsewhere (Böhlke et al., 1984; Alt et al., 1986b). Stable temperature ranges for the zeolites identified in Hole $765 \mathrm{D}$ are generally $\leq 50^{\circ} \mathrm{C}$ in oceanic environments (Honnorez, 1978; Kristmannsdöttir and Tömasson, 1978; Böhlke et al., 1984).

\section{Evidence for High-Temperature Alteration}

Partial albitization of plagioclase (generally $10 \%$ ) occurs in most samples and may be associated with analcime, Na-rich natrolite, or chabazite. Albitized plagioclase is not spatially associated with the halos, and its presence is not influenced by the 
Table 6. Calculated elemental fluxes, Hole 765D.

\begin{tabular}{|c|c|c|c|c|c|c|c|}
\hline \multirow{2}{*}{$\begin{array}{l}\text { Core, section, } \\
\text { interval }(\mathrm{cm}) \\
\text { Flux }\end{array}$} & \multirow{2}{*}{$\begin{array}{c}7 \mathrm{R}-3, \\
0-7 \\
\mathrm{Or} / \mathrm{Fr}\end{array}$} & \multicolumn{2}{|c|}{$9 \mathrm{R}-1,82-90$} & \multirow{2}{*}{$\begin{array}{c}19 \mathrm{R}-1, \\
115-121 \\
\mathrm{Gr} / \mathrm{Fr}\end{array}$} & \multicolumn{2}{|c|}{$23 R-2,72-76$} & \multirow{2}{*}{$\begin{array}{l}25 \mathrm{R}-1, \\
34-41 \\
\mathrm{Or} / \mathrm{Fr}\end{array}$} \\
\hline & & $\mathrm{Or} / \mathrm{Fr}$ & $\mathrm{Gr} / \mathrm{Fr}$ & & $\mathrm{Or} / \mathrm{Fr}$ & $\mathrm{Gr} / \mathrm{Fr}$ & \\
\hline $\mathrm{SiO}_{2}$ & 0.98 & 0.98 & 0.99 & 0.98 & 0.93 & 1.00 & 0.99 \\
\hline $\mathrm{TiO}_{2}$ & 0.93 & 0.94 & 0.94 & 0.98 & 0.97 & 1.01 & 1.01 \\
\hline $\mathrm{Al}_{2} \mathrm{O}_{3}$ & 0.96 & 0.92 & 0.93 & 0.97 & 0.94 & 1.01 & 0.90 \\
\hline $\mathrm{Fe}_{2} \mathrm{O}_{3}$ & 1.24 & 1.40 & 1.25 & 1.23 & 1.77 & 1.15 & 1.35 \\
\hline $\mathrm{MgO}$ & 0.87 & 0.80 & 0.80 & 0.95 & 0.79 & 0.83 & 0.97 \\
\hline $\mathrm{MnO}$ & 1.04 & 1.20 & 1.21 & 1.05 & 1.27 & 0.90 & 1.11 \\
\hline $\mathrm{CaO}$ & 0.95 & 0.97 & 0.95 & 0.86 & 0.94 & 0.93 & 0.87 \\
\hline $\mathrm{Na}_{2} \mathrm{O}$ & 1.18 & 0.90 & 0.91 & 0.94 & 0.98 & 1.01 & 1.08 \\
\hline $\mathrm{K}_{2} \mathrm{O}$ & 2.41 & 19.81 & 20.81 & 2.92 & 3.15 & 6.92 & 1.65 \\
\hline $\mathrm{P}_{2} \mathrm{O}_{5}$ & 0.91 & 0.95 & 0.99 & 0.99 & 1.04 & 1.00 & 0.99 \\
\hline
\end{tabular}

Note: Values greater than 1 indicate enrichment, values less than 1 indicate depletion; only values greater than 1.1 and less than 0.9 are considered significant. Or $=$ orange zone; $\mathrm{Gr}=$ green zone; $\mathrm{Fr}=$ adjacent "fresh" whole rock. Ratios were calculated using bulk-rock compositions normalized to $100 \%$ on a volatile-free basis.

degree of alteration (i.e., percentage of clay minerals). Albitization of the anorthitic component of plagioclase requires the addition of $\mathrm{Na}^{+}$and $\mathrm{SiO}_{2}(\mathrm{aq})$ and indicates a reaction with solutions with a high $\mathrm{Na}^{+} / \mathrm{Mg}^{+}$ratio (e.g., Seewald, 1987). If $\mathrm{Na}-\mathrm{Ca}$ zeolites formed prior to albite, the transformation of zeolite to albite should require the addition of variable amounts of $\mathrm{Al}, \mathrm{Si}$, and $\mathrm{Na}$. For example, the transformation of either analcime or mesolite to albite requires the addition of $\mathrm{SiO}_{2}$ and, possibly, $\mathrm{Al}^{3+}$ (Liou, 1971), both of which might be locally derived by the hydrolysis of basalt. The transformation of igneous plagioclase or zeolites to albite occurs at temperatures $\geq 100^{\circ} \mathrm{C}$ in geothermal and burial metamorphic terrains (Liou, 1971; Kristmannsdöttir and Tömasson, 1978).

The partial albitization of plagioclase in the basalts at Hole $765 \mathrm{D}$ is problematical as the clay mineral and zeolite assemblages and bulk-rock geochemistry indicate that seawater-rock interaction occurred at temperatures $<50^{\circ} \mathrm{C}$. In contrast, albitized plagioclase in oceanic rocks and ophiolites occurs at the lava/dike transition and within sheeted dike complexes where temperatures are inferred to be $\geq 100^{\circ} \mathrm{C}$ (Alt et al., 1986a; Gillis and Robinson, 1990). Possible alteration histories, where a segment of shallow oceanic crust undergoes both low- and high-temperature alteration, are reviewed in the following section and their applicability to Hole 765 is considered.

1. Open-system hydrothermal convection. Albitization may occur during an initial stage of high-temperature alteration, presumably at a ridge axis, prior to the formation of low-temperature secondary phases. Because the shallow crust is a high-permeability environment, high temperatures can be maintained only within focused hydrothermal discharge zones. If the crust at Hole 765D passed through a zone of upwelling, the rocks should resemble hydrothermal alteration pipes in ophiolites, where lavas have been pervasively altered to greenschist facies mineral assemblages and overprinted by low-temperature minerals (e.g., Troodos ophiolite; Richards et al., 1989).

2. Closed-system hydrothermal convection. Albitization may occur in an off-axis setting, where the basement is open to fluid circulation, but is sealed from cold seawater penetration by an impermeable sedimentary cover. In such a closed environment, it is possible that hydrothermal circulation might cause isotherms to move up in the crust, producing high temperatures near the lava/sediment boundary. However, circulation of hot hydrothermal fluids should reset the low-temperature O-isotope signature of the rocks and might lead to the addition of other components, such as Ca-rich phases, neither of which occurred at Hole 765D.

3. Conductive reheating of oceanic crust. Albitization may occur off-axis, after the crust has been sealed from cold seawater penetration by the deposition of an impermeable sedimentary cover and precipitation of secondary minerals in voids has lowered the permeability of the crust below the level necessary for circulation. Conductive reheating of the crust, as result of the conductive heat flow in the lithosphere, should lead to the prograde reaction of plagioclase or zeolites to albite (Kuniyoshi and Liou, 1976). To reach the temperatures required for albitization in the shallow crust, heat-flow values that are typical of young oceanic crust would be required. Because only in-situ interstitial fluids should be present in this setting, the $\mathrm{O}$-isotopic composition of the rocks should not be reset and there would be no addition of components of high-temperature hydrothermal alteration.

An alteration history that involves conductive reheating is the most applicable scenario for Hole 765D. Although the stratigraphy of the sediment sequence indicates that the basement section at Site 765 remained open for several million years, the alteration characteristics of the Hole 765D core suggest that the crust was sealed from seawater penetration early in its history. To resolve this discrepancy, additional data are required.

A similar model can be envisaged for DSDP/ODP Hole 504B, where the secondary mineral assemblages (Alt et al., 1986a), current basement temperatures (Shipboard Scientific Party, 1988), and magnetic properties (e.g., Curie temperature; Pariso and Johnson, in press) suggest that the lower few hundred meters of the volcanic section was initially altered at low temperatures and has been reheated subsequently to temperatures $>100^{\circ} \mathrm{C}$. Thus, crustal reheating may be a common process in oceanic crust generated in sedimented environments. As the metamorphic reactions observed in reheated oceanic crust do not require an external fluid source, off-axis reheating of the crust should result in isochemical exchange, and the bulk composition of the crust should not be modified further.

\section{CONCLUSIONS}

The volcanic basement recovered at Hole 765D underwent low-temperature oxidative alteration that is typical of most shallow crustal sections recovered by DSDP/ODP. Well-developed alteration halos parallel fracture surfaces throughout the core and exhibit consistent mineralogical and geochemical zonations. The scarcity of saponite suggests that the rocks were exposed only to oxygenated seawater and that the duration of seawater circulation was short-lived. Albitization of plagioclase in this shallow basement section indicates that the section of crust sampled at Hole $765 \mathrm{D}$ was initially altered at low temperatures and was reheated off-axis by conductive heat flow in a closed environment. Reheating did not result in significant modification of the bulk composition of the crust. 


\section{ACKNOWLEDGMENTS}

This research was funded by Natural Sciences and Engineering Research Council (NSERC) grants to JNL. We thank Steve Recca for his assistance with the microprobe analyses, Brigitte Dionne for her assistance in the laboratory, and Margaret Sulanowska for her help with the figures. Discussions with R. Von Herzen were helpful. Thoughtful reviews by $\mathrm{H}$. Richards and $\mathrm{H}$. Staudigel are appreciated.

\section{REFERENCES}

Adamson, A. C., and Richards, H. G., 1990. Low-temperature alteration of very young basalts from ODP Hole 648B: Serocki volcano, MidAtlantic Ridge. In Detrick, R., Honnorez, J., Bryan, W. B., Juteau, T., et al., Proc. ODP, Sci. Results, 106/109: College Station, TX (Ocean Drilling Program), 181-194.

Alt, J. C., and Honnorez, J., 1984. Alteration of the upper oceanic crust, DSDP Site 417: mineralogy and chemistry. Contrib. Mineral. Petrol., 87:149-169.

Alt, J. C., Honnorez, J., Laverne, C., and Emmermann, R., 1986a. Hydrothermal alteration of a $1 \mathrm{~km}$ section through the upper oceanic crust, Deep Sea Drilling Project Hole 504B: mineralogy, chemistry, and evolution of seawater-basalt interactions. J. Geophys. Res., 91: 10309-10335.

Alt, J. C., Muehlenbachs, K., and Honnorez, J., 1986b. An oxygen isotopic profile through the upper kilometer of the oceanic crust, DSDP Hole 504B. Earth Planet. Sci. Lett., 80:217-229.

Andrews, A. J., 1980. Saponite and celadonite in Layer 2 basalts, DSDP Leg 37. Contrib. Mineral. Petrol., 73:323-340.

Baertschi, P., 1976. Absolute ${ }^{18} \mathrm{O}$ content of standard mean ocean water. Earth Planet. Sci. Lett., 31:341.

Barrows, K. J., 1980. Zeolitization of Miocene volcaniclastic rocks, southern Desatoya Mountains, Nevada. Geol.Soc. Am. Bull., 91:199210 .

Bass, M. N., 1976. Secondary minerals in oceanic basalt, with special reference to Leg 34, Deep Sea Drilling Project. In Yeats, R. S., Hart, S. R., et al., Init. Repts. DSDP, 34: Washington (U.S. Govt. Printing Office), 393-432.

Böhlke, J. K., Alt, J. C., and Muehlenbachs, K., 1984. O isotope-water relations in altered deep-sea basalts: low temperature mineralogical controls. Can. J. Earth Sci., 21:67-77.

Böhlke, J. K., Honnorez, J., and Honnorez-Guerstein, B. M., 1980. Alteration of basalts from Hole 396B, DSDP: petrographic and mineralogical studies. Contrib. Mineral. Petrol., 73:341-364.

Boles, J. R., 1972. Composition, optical properties, cell dimensions and the thermal stability of some heulandite group zeolites. Am. Mineral., 57:1463-1493.

Clayton, R. N., and Mayeda, T. K., 1963. The use of bromine pentafluoride in the extraction of oxygen from oxides and silicates for isotopic analysis. Geochim. Cosmochim. Acta, 27:43-52.

Donnelly, T. W., Pritchard, R. A., Emmermann, R., and Puchelt, H., 1979. The aging of oceanic crust: synthesis of the mineralogical and chemical results of Deep Sea Drilling Project, Legs 51 through 53. In Donnelly, T., Francheteau, J., Bryan, W., Robinson, P., Flower, M., Salisbury, M., et al., Init. Repts. DSDP, 51, 52, 53: Washington (U.S. Govt. Printing Office), 1563-1577.

Fullerton, L. G., Sager, W. W., and Handschumacher, D. W., 1989. Late Jurassic-Early Cretaceous evolution of the eastern Indian Ocean adjacent to northwest Australia. J. Geophys. Res., 94:2937-2953.

Gillis, K. M., and Robinson, P. T., 1988. Distribution of alteration zones in the upper oceanic crust. Geology, 16:262-266.

, 1990. Patterns and processes of alteration in the lavas and dykes of the Troodos Ophiolite, Cyprus. J. Geophys. Res., 95:21523-21548.

Hey, R. L., 1966. Zeolites and zeolitic reactions in sedimentary rocks. Spec. Pap. Geol. Soc. Am., 85:1-130.
Honnorez, J., 1978. Generation of phillipsites by palagonitization of basaltic glass in sea water and the origin of $\mathrm{K}$-rich deep-sea sediments. In Sand, L. B., and Mumpton, F. A. (Eds.), Natural Zeolites: Occurrence, Properties and Use: New York (Pergamon Press), 245-258. 1981. The aging of the oceanic crust at low temperature. In Emiliani, C. (Ed.), The Sea (vol. 7): New York (Wiley), 525-587.

Klein, E. M., and Langmuir, C. H., 1987. Global correlations of ocean ridge basalt chemistry with axial depth and crustal thickness $J$. Geophys. Res., 92:8089-8115.

Klein, E. M., Langmuir, C. H., and Staudigel, H. S., 1991. Geochemistry of basalts from the SE Indian Ridge, $115^{\circ}-138^{\circ}$. J. Geophys. Res. 96:2089-2108.

Kristmannsdöttir, H., and Tömasson, J., 1978. Zeolite zones in geothermal areas in Iceland. In Sand, L. B., and Mumpton, F. A. (Eds.), Natural Zeolites: Occurrences, Properties, and Use: Oxford (Pergamon Press), 277-284.

Kuniyoshi, S., and Liou, J. G., 1976. Burial metamorphism of the Karmutsen volcanic rocks, northeastern Vancouver Island, British Columbia. Am. J. Sci., 276:1096-1119.

Liou, J. G., 1971. Analcime equilibrium. Lithos, 4:389-402.

Muehlenbachs, K., 1979. The alteration and aging of the basaltic layer of the sea floor: oxygen isotope evidence from DSDP/IPOD Legs 51, 52, and 53. In Donnelly, T., Francheteau, J., Bryan, W., Robinson, P., Flower, M., Salisbury, M., et al., Init. Repts. DSDP, 51, 52, 53 (Pt. 2): Washington (U.S. Govt. Printing Office), 1159-1167.

Mumpton, F. A., 1960. Clinoptilolite redefined. Am. Mineral., 45:351369.

Pariso, J. E., and Johnson, P., in press. Crustal formation processes at Hole 504B: implications for magnetization of oceanic crust. J. Geophys. Res.

Richards, H., Cann, J. R., and Jensenius, J., 1989. Mineralogical zonation and metasomatism of the alteration pipes of Cyprus sulfide deposits. Econ. Geol., 84:91-115.

Ross, C. S., and Hendricks, S. B., 1945. Minerals of the montmorillonite group: their origin in relation to soils and clays. Geol. Surv. Prof. Pap. U.S., 205B:23-79.

Seewald, J. S., 1987. Na and Ca metasomatism during hydrothermal basalt alteration: an experimental and theoretical study [M.S. thesis]. Univ. of Minnesota, Minneapolis.

Seyfried, W. E., Jr., Shanks, W. C., III, and Dibble, W. E., Jr., 1978. Clay mineral formation in DSDP Leg 34 basalt. Earth Planet. Sci. Lett., 41:265-276.

Shipboard Scientific Party, 1988. Site 504, Costa Rica Rift. In Becker, K., Sakai, H., et al., Proc. ODP, Init. Repts., 111: College Station, TX (Ocean Drilling Program), 35-251.

1990. Site 765. In Gradstein, F. M., Ludden, J. N., et al., Proc. ODP, Init. Repts., 123: College Station, TX (Ocean Drilling Program), 63-267.

Stakes, D. S., and O'Neill, J. R., 1982. Mineralogy and stable isotope geochemistry of hydrothermally altered oceanic rocks. Earth Planet. Sci. Lett., 57:285-304.

Staudigel, H., and Hart, S. R., 1985. Dating of ocean crust hydrothermal alteration: strontium isotope ratios from Hole 504B carbonates and a reinterpretation of $\mathrm{Sr}$ isotope data from Deep Sea Drilling Project Sites 105, 332, 417, and 418. In Anderson, R. N., Honnorez, J., Becker, K., et al., Init. Repts. DSDP, 83: Washington (U.S. Govt. Printing Office), 297-303.

Staudigel, H., Hart, S. R., and Richardson, S. H., 1981. Alteration of the oceanic crust: processes and timing. Earth Planet. Sci. Lett., 52:311327.

Wise, W. S., and Eugster, H. P., 1964. Celadonite: synthesis, thermal stability and occurrence. Am. Mineral., 49:1031-1083.

Date of initial receipt: 27 June 1990

Date of acceptance: 8 January 1991

Ms 123B-157 